\title{
W. H. WILMER, of Washington
}

The death of Dr. William Holland Wilmer was briefly recorded on page 255. A memoir of him appeared in the June issue of the A merican Journal of Ophthalmology from which the following facts are abstracted.

Wilmer was the son of the Rev. Richard Hooker Wilmer and was born in 1863, in Virginia. He had his medical education at Virginia University and took his degree in 1885 . He then served an internship at a New York Hospital, and after two years as assistant to Dr. Emil Gruening; he began practice at Washington in 1889. In 1897 he took an active share in the foundation of the Episcopal Fye, Ear and Throat Hospital, and in 1906 became Professor of Ophthalmology in Georgetown University. In 1917 he became Major in the Medical Corps of the United States Army, and served in charge of a Research Laboratory for Air Service at Mineola. He rose to be Brigadier-Creneral in the Medical Reserve Corps.

The Wilmer Ophthalmological Institute of Johns Hopkins University is a tribute to his standing as an ophthalmologist in the States. Before the buildings were planned Wilmer gave up his practice at Washington and went to Baltimore to organize his new Institute. He came to Europe to study the great hospitals and in 1927 started work in temporary quarters. The Institute was formally opened in 1929, with addresses from Ernst Fuchs, Dr. George de Schweinitz and Sir John Parsons.

Until last year, when he reached the retiring age, Wilmer was in charge of this great Institute, and on ceasing to hold the Directorship he went home to Washington and resumed private practice. Wilmer died suddenly of a heart attack on March 12,1936; his body was buried in the grounds of Washington Cathedral.

Besides being a specially skilled ophthalmic surgeon Wilmer had the kindest of hearts and was loved by a large circle of patients and friends. Dr. Edward Jackson writes: "His was a balanced character. He was the same to a negro woman in his clinic, or the British nobleman, or French ambassador, to Charles Lindbergh, or the King of Siam."

Dr. Wilmer held the Distinguished Service Medal and the Cross of a Commander of the Legion d'honneur.

He did not write much, and his magnificent atlas on the Fundus Oculi is his chief work.

Perhaps the writer of this notice might mention that though Wilmer and he had never met, he was the recipient of many kind and congratulatory letters at various times during the past few years. That he should have found time in his busy work to write to an unknown author was characteristic of the man. 